\title{
The Environmental Factors Affecting Transfer of Training: Tehran Municipality Employees
}

\author{
Mojgan Abdollahi (Corresponding author) \\ Faculty member of Islamic Azad University Karaj Branch \\ Phycology School, Department of Educational Administration, Iran \\ E-mail: mabdollahi49@gmail.com
}

Somayeh Daneshmandi,

Ph.D. Candidate, Shahid Beheshti University, Iran

Received: June 29, 2017 Accepted: August 11, 2017 Published: August 17, 2017

doi:10.5296/ijld.v7i3.11478 URL: https://doi.org/10.5296/ijld.v7i3.11478

\begin{abstract}
The present study explored the effect of environmental factors on transfer of training from training courses to the workplace. The study is a quantitative method. The population contained all of the employees participated in the training courses of the population consisted of all Employees who participated in in-service training courses in Tehran Municipality in $2015(\mathrm{~N}=385)$. The sample included 193 persons selected by simple random sampling technique. The tools used for data collection were questionnaire. The data gathered was analyzed using t-test and exploratory factor analysis. The results showed that the most important factor influencing transfer of training was Opportunity to use capabilities.
\end{abstract}

Keywords: Transfer, transfer of training, environmental factors 


\section{Introduction and Problem Statement}

Since the governments, industries, and individuals invest in education and training of skills, they expect the training programs develop students' capability to transfer learned contents to new and different areas. There are many concerns about lack of complete transfer of educational contents to everyday workplace situations.

The long-term success of any organization depends largely on whether the employees of organization are effectively and continuously learning and utilizing new information to improve their business performance that is beneficial to organization. Therefore, the continuous training of employees is a key element in ensuring the future of organization (Schneider, Pältz, \& Stauche, 2014). The training is one of the vital strategies of organization which helps employees to achieve necessary attitudes, skills, and knowledge to deal with changes and challenges. Although there are different objectives or necessities for organizational training, undoubtedly the most important goal of organizational training is changing performance of employees to improve the quality and quantity of organization's products or services.

The transfer of training is an issue which has attracted the attention of many education researchers and human resource development managers. The scholars have provided many definitions for training transfer (Taghavi Fard, Rahimiyan, \& Najafi, 2015). According to cognitive approach, the training learning is a dynamic and complex phenomenon. There is increasing convergence among theoreticians about how to describe what is happened cognitively among learners when faced with a new problem or field (Lebermann, McDonald, \& Doyle, 2006).

In spite of high attention to education and training programs, studies have shown that most of these programs are not effective. In other words, these programs lead to little transfer of learned skills to workplace as one of the most important indicators of educational programs effectiveness. The studies have shown that only about 40 percent of employees learning in educational programs are transmitted immediately after training to workplace. After 6 months, this value is reduced to 25 percent and after one year, it is reduced to 15 percent; this means that over time, the students are not able to retain and apply the learned information (Wexley \& Latham, 2002). This indicates that most of time and costs are wasted in educational programs. However, the employees should apply their learned materials in workplace (transfer of training) to make effective the investment of organization in education sector (Velada \& Caetano, 2007).

In recent studies it has found that In fact, typical estimates of skills lost due to poor transfer of training range from $66 \%$ to $90 \%$ (Sookhai \& Budworth, 2010). In addition, only 21 percent of interested organizations assess the level of transfer of training of their employees (Lim \& Nowell, 2014). Frequently associated when the employees can use what they have learned at the workplace (Bouzguenda, 2014) and percentage of applying the learned knowledge is low (Mohammed Turab \& Casimir, 2015).

Doyle (2002) believes that the training transfer takes place when the learner applies the 
learned material in new and different position. All education and training aims to transfer the learned contents. The research suggests that it is difficult to achieve the training transfer. It is vital to understand what helps the training transfer and what prevents it (Doyle, 2002).

The training transfer includes the process of applying knowledge, skills, attitudes, and features which are achieved in a training program to improve productivity, efficiency, and job satisfaction. In order to avoid losses from weakened performance, it is critical that the managers and participants in educational programs consider training transfer as a major component of educational process (Abazed, Melanie, \& Sassi, 2008). In general, the education aims to help learners transfer the learned materials in a training course to real world (Schmitz, 2009) and the training transfer aims to increase the return on investment of training (Velada \& Caetano, 2007). In this regard, the organizations should identify the variables and factors affecting transition process and consider them. In general, the transfer process is influenced by three factors: learner's characteristics, training design, and workplace. Goldstein demonstrated that the workplace environment components may actually lead to more transfer than any other education aspects (Schmitz, 2009).

According to above, this study aims to investigate the impact of workplace environmental factors (management support, peer support, technological support, and opportunity to apply capabilities (Noe, 2010)) on transferring of learned materials by Employees.

Given this main objective, the following four questions are proposed:

1) What is the role of management support in transfer of training?

2) What is the role of peer support in transfer of training?

3) What is the role of technology support in transfer of training?

4) What is the role of opportunity to apply the capabilities in transfer of training?

\section{Environment Factors Affecting Transfer Process}

The environmental factors affecting transfer of training include the elements of work environment which are commonly found in most of educational perspectives. Different researchers have determined the importance of environmental features and have studied the variables which are important for success of educational efforts. The work-related elements may, in principle, lead to more transfer than other aspects of education (Freemtmann \& Ron, 2015). The organizational factors affecting transfer of training include a variety of factors such as colleagues support, supervisor support, supervisor's inhibition, positive individual results, negative individual results, supervisor's permission, application opportunity, expectations of performance outcomes, and expectations from transmission outcomes (Halton, 2000). Ford, Baldwin, and Halton (2005) examined the work environment variables which affect transfer of training. These studies referred to two aspects of work environment: organizational climate and culture (Baldwin \& Ford, 1988; Holton, 2005).

The environmental factors of motivation considered are: (1) opportunities for utilization of training; (2) peer support; (3) supervisor approval; and (4) supervisor support (gil, Molina \& Ortega, 2016). 
In general, the most important factors influencing the transfer process may be described as follows:

Management support: the support of managers from training is another known factor in training transfer (Landsman, 2007; Brook and Hotchains, 2008; Morbarak, 2009; Auerbach, McGowan \& LaPorte, 2008; Shams \& Daneshmandi, 2014). The research suggest that when employees find that their managers support the application of new knowledge and skills in workplace, they have more tendency to transfer the training to workplace (Velada \& Caetano, 2007).

Peer support: The training transfer may also be promoted through a supportive network among employees. The supportive network includes a group of two or more employees or learners who help each other and discuss about the process of using learners materials in workplace. This support may include face to face meetings or communicating via email (Noe, 2010).

Technological support: The electronic functional supportive systems are computer devices which may provide academic skills, access to information, and specialized tools. These systems may promote the training transfer of individuals through equipping them with electronic resources available for use in workplace (Noe, 2010).

Opportunity to use capabilities: the use opportunity has positive and significant impact on transfer of new obtained knowledge, skills, and attitudes (Brooke \& Hotchines, 2008). The opportunity to use learned skills refers to a situation in which the individuals actively seek experiences which gave them the opportunity to apply the new knowledge, skills, and behaviors which are learned from training program. The opportunity to use learned skills is influenced by two factors: work environment and learner's motivation. The specific work experience is one of the areas in which the individuals may use their capabilities. The opportunity to apply is determined through scope, level of activity, and type of duty. The scope includes a set of trained tasks which are performed during the job. The level of activity is the frequency of using trained tasks in job. The duty type refers to difficult or sensitive nature of tasks which are actually done in job. The learners who have the opportunity to use educational content in work retain more learned skills than those who have fewer opportunities (Noe, 2010).

\section{Methodology}

This was applied quantitative study. The library (investigating theoretical and research data) and survey (evaluating the comments and views of samples) study was used for collecting the data. The population consisted of all Employees who participated in in-service training courses in Tehran Municipality in $2015(\mathrm{~N}=385)$. Using Cochran formula, the sample size was determined to be 193 participants; the participants were selected using random sampling method. Shams Moorkani and Daneshmandi's standard questionnaire (2014) was used for collecting the data; it included 12 items and used Likert scale. The first three items evaluated management support of training transfer; the items 4- 6 measured peer support of training support; and the items 7-9 and 10-12 investigated technological support and opportunity to 


\section{Macrothink}

International Journal of Learning and Development

ISSN 2164-4063

2017, Vol. 7, No. 3

use, respectively. Using Cronbach's alpha coefficient, the reliability was determined to be 0.90. The collected data were analyzed using exploratory factor analysis and one-group t-test.

\section{Findings}

\subsection{Demographic Characteristics}

From among the participants ( $n=143), 27 \%$ were men and $73 \%$ were women. However, $49 \%$ were younger than 50 years old and $51 \%$ were 50 years and older. And, $49 \%$ and $51 \%$ of participants participated in training courses 10 times and more than 10 times, respectively.

\subsection{Exploratory Factor Analysis}

The exploratory factor analysis was used to detect the main structures of data, identify affecting factors, proportion of variance explained by these factors, and prioritizing them in in transfer of training. The process and findings were as follows.

\subsection{Good Correlation Matrix:}

The data matrix for factor analysis must contain significant information. The significance of information in a matrix is determined through Bartlett chi-square test $(2 \chi)$. The KMO index is one of the ways to determine the measure of how fit your data is for Factor Analysis. The KMO index measures sampling adequacy for each variable in the model and low partial correlation between variables. The statistic is a measure of the proportion of variance among variables that might be common variance; KMO returns values between 0 and 1 .

If the value of this statistic is more than 0.70 , the correlation is generally suitable for factor analysis. If $\mathrm{KMO}$ is 0.50 to 0.69 , it requires special attention. If the value is less than 0.50 , it means that the factor analysis is not suitable for that set of variables. According to Table 1, the results of the above tests are suitable for factor analysis of research data; the KMO index value is equal to 0.845 . Also, the Bartlett's test shows high correlation between variables (non-unit correlation matrix) and suitability of this method. The significance level of this test is 0.000 ; this value is less than 0.05 and therefore, the null hypothesis (unit correlation matrix) is rejected. The results of both indices show the suitability of factor analysis for research data.

Table 1. KMO and Bartlett's test results

\begin{tabular}{ll}
\hline KMO & 0.845 \\
\hline Chi-square test & 1240.279 \\
Degree of freedom & 66 \\
standard error & 0.000 \\
\hline
\end{tabular}

\subsection{Extracting Primary Factors}

After the above tests, the exploratory factor analysis was conducted to identify the main 


\section{Macrothink}

International Journal of Learning and Development

ISSN 2164-4063

2017, Vol. 7, No. 3

factors, their specific features, and relationship between them. The eigenvalue statistics is one of the most common ways to determine the appropriate factors; it represents the variance in primary factors. In other words, the eigenvalue of each factor is the variance of all factors which is explained by that factor; the higher this value, the factor explains more variance. The best factors are those which have eigenvalue of more than one.

The eigenvalue of 12 items is more than one and the percentage of common variance among these 3 items explains $67.49 \%$ of total variance. In other words, the accuracy of these 3 items is more than 67 percent. The first item (eigenvalue $=5.45 \%$ ) explains about $45.42 \%$ of variance in variables.

To determine that the scale is saturated by some significant factors, three main indices were considered: 1) eigenvalue, 2) variance ratio determined by each factor, and 3) rotated chart of eigenvalues which are called Scree.

The sloping plot shows the total variance which is explained by each variable in relation to other variables. This plot usually shows the big factors in above; other factors are shown together with a gradual slope. This plan which is as hillside steep is called Scree by Cattell Scree. The evidence show that if $\mathrm{k}$ is the number of natural factors, the Scree starts from $k_{t h}$ factor. In fact, this curve is the difference between eigenvalues which defines the steep chart's milestone. It is assumed that all factors in right side of chart are error factors. The larger the eigenvalue, the common factor will be significant; so, the steep graph facilities the determination of common factors which are eligible for maintain factors. According to Scree diagram in Figure 1, it may be deduced that the contribution of first item in total variance of variables is dramatic and is quite distinct from other factors. However, the slope is flattened after third factor (third item); in fact, the flattened diagram begins from third factor.

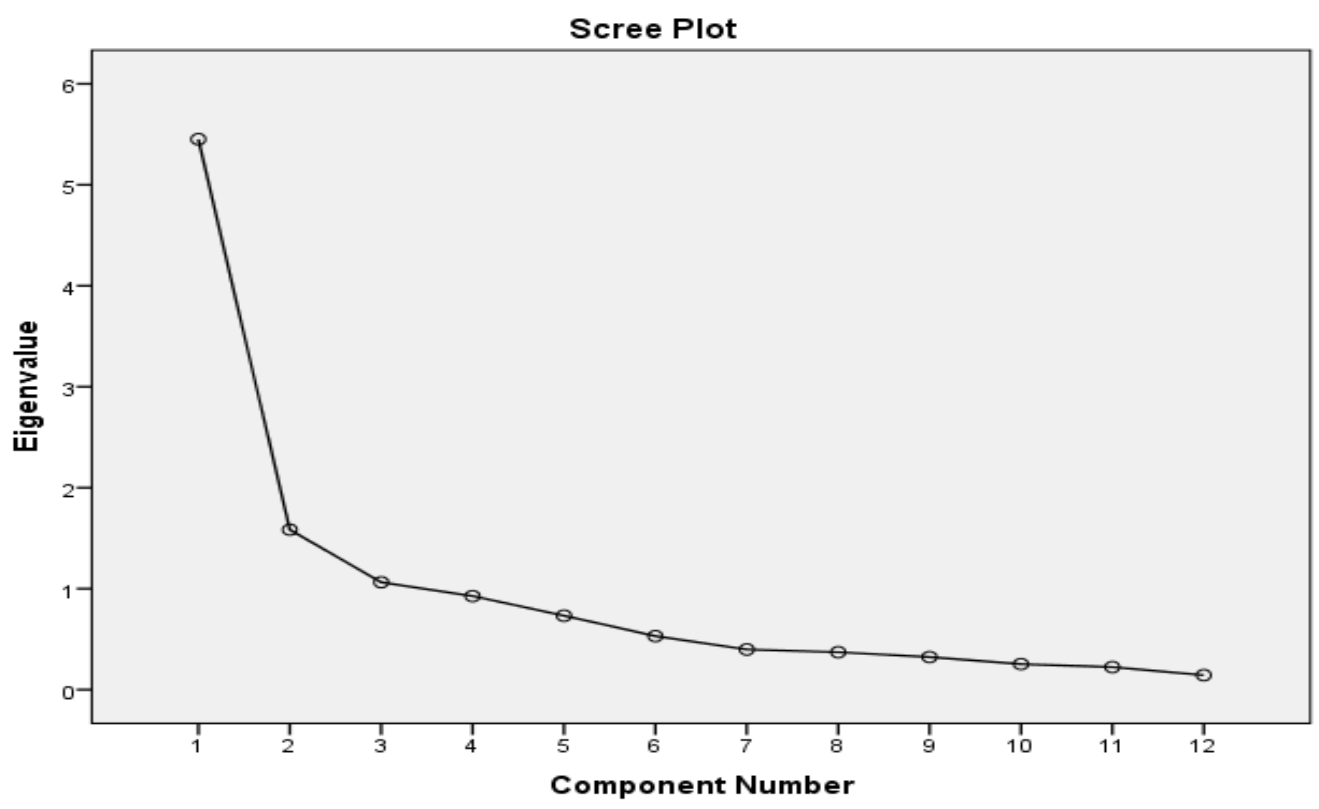

Figure 1. Scree graph of factors affecting transfer of training 


\section{Macrothink}

International Journal of Learning and Development

ISSN 2164-4063 2017, Vol. 7, No. 3

According to results of factor analysis and indices which were mentioned earlier, three extracted items explained $67.49 \%$ of total variance. The first (eigenvalue $=5.45$ ), second $($ eigenvalue $=1.58)$, and third (eigenvalue $=1.06)$ items explained $45.42,13.19$, and 8.86 percent of total variance, respectively. The eigenvalue and variance percentage, and cumulative percentage of three items are shown in Table 2.

Table 2. Eigenvalue, variance percentage, and cumulative percentage of items

\begin{tabular}{llll}
\hline Components & Eigenvalue & Percentage of explained variance & Cumulative percentage \\
\hline Item 1 & 5.45 & 45.42 & 45.42 \\
Item 2 & 1.58 & 13.19 & 58.62 \\
Item 3 & 1.06 & 8.86 & 67.49 \\
Item 4 & 0.92 & 7.71 & 75.20 \\
Item 5 & 0.73 & 6.10 & 81.31 \\
Item 6 & 0.53 & 4.41 & 85.73 \\
Item 7 & 0.39 & 3.31 & 89.04 \\
Item 8 & 0.37 & 3.09 & 92.13 \\
Item 9 & 0.32 & 2.69 & 94.83 \\
Item 10 & 0.25 & 2.10 & 96.94 \\
Item 11 & 22. & 1.86 & 98.80 \\
Item 12 & 0.14 & 1.19 & 100.000 \\
\hline
\end{tabular}

In terms of common things of 12 items, the least common thing $(0.464)$ is for item 10 (motivation to use learned capabilities in work place) and the most common thing $(=0.810)$ is for item 12 (daily work tasks do not let to use learned capabilities in job). The common thing rate of other factors is between these two values.

\subsection{Rotation and Final Selection of Factors}

After determining the factors number, the variables of each factor should be determined. The primary factors determination does not determine the variables of each factor. Many variables are often weighted by some factors and some of the factors almost include all variables. Therefore, the factor rotation is conducted to interpret the factors; it aims to achieve factors which include some variables. The factor rotation matrix is shown in Tables 4 and 5. This matrix is essential in interpreting the results of factor analysis. Any variable that has a greater load on a factor belongs to it. The factor loading of 0.30 indicates that $9 \%$ of variance is explained by that factor. This explained variance value shows that the factor loading is significant. Therefore, in factor analysis of 100 people, the factor loading of 0.3 is a reasonable criterion. The loading 0.3 and above is considered significant. On the other hand, 


\section{Macrothink}

International Journal of Learning and Development

ISSN 2164-4063 2017, Vol. 7, No. 3

if a variable is loaded in more than two times, the variable should be included in a factor which has the highest load in it. The Table 4 shows the share of variables in factors before the rotation.

Table 3. Un-rotated factor structure matrix through PC

\begin{tabular}{llll}
\hline \multirow{2}{*}{ Items } & Factors & Second & Third \\
\cline { 2 - 4 } & Frist & -0.207 & -0.135 \\
\hline First & 0.794 & -0.287 & -0.152 \\
Second & 0.796 & -0.235 & -0.008 \\
Third & 0.790 & -0.355 & -0.115 \\
Fourth & 0.732 & 0.367 & 0.069 \\
Fifth & 0.688 & -0.232 & 0.003 \\
Sixth & 0.723 & 0.557 & -0.217 \\
Seventh & 0.646 & 0.633 & -0.202 \\
Eighth & 0.630 & 0.595 & 0.057 \\
ninth & 0.629 & 0.63 & 0.384 \\
Tenth & 0.559 & 0.98 & 0.134 \\
Eleventh & 0.675 & 0.103 & 0.865 \\
Twelfth & 0.228 & &
\end{tabular}

The following table shows the share of variables in factors after rotation. Each variable is included in a factor which has significant high correlation with it. 
Table 4. Rotated factor structure matrix through PC

\begin{tabular}{llll}
\hline Items & Factors & Third \\
\cline { 2 - 4 } & First & 0.282 & 0.031 \\
\hline First & 0.782 & 0.222 & 0.006 \\
Second & 0.830 & 0.229 & 0.149 \\
Third & 0.777 & 0.123 & 0.020 \\
Fourth & 0.813 & 0.051 & 0.187 \\
Fifth & 0.759 & 0.194 & 0.145 \\
Sixth & 0.719 & 0.846 & -0.005 \\
Seventh & 0.241 & 0.897 & 0.015 \\
Eighth & 0.183 & 0.811 & 0.261 \\
ninth & 0.169 & 0.268 & 0.507 \\
Tenth & 0.368 & 0.412 & 0.295 \\
Eleventh & 0.477 & 0.021 & 0.900 \\
Twelfth & 0.012 & & \\
\hline
\end{tabular}

The following table shows the correlation coefficients between factors before and after rotation.

Table 5. Eigenvalue, variance percentage, and cumulative percentage of factors

\begin{tabular}{llll}
\hline Components & 1 & 2 & 3 \\
\hline 1 & 0.815 & 0.532 & 0.230 \\
2 & -0.564 & 0.819 & 0.103 \\
3 & -0.133 & -0.213 & 0.968 \\
\hline
\end{tabular}

The Figure 2 shows the rotated three-dimensional graph. This graph shows the distribution of variables compared with first, second, and third factors. 


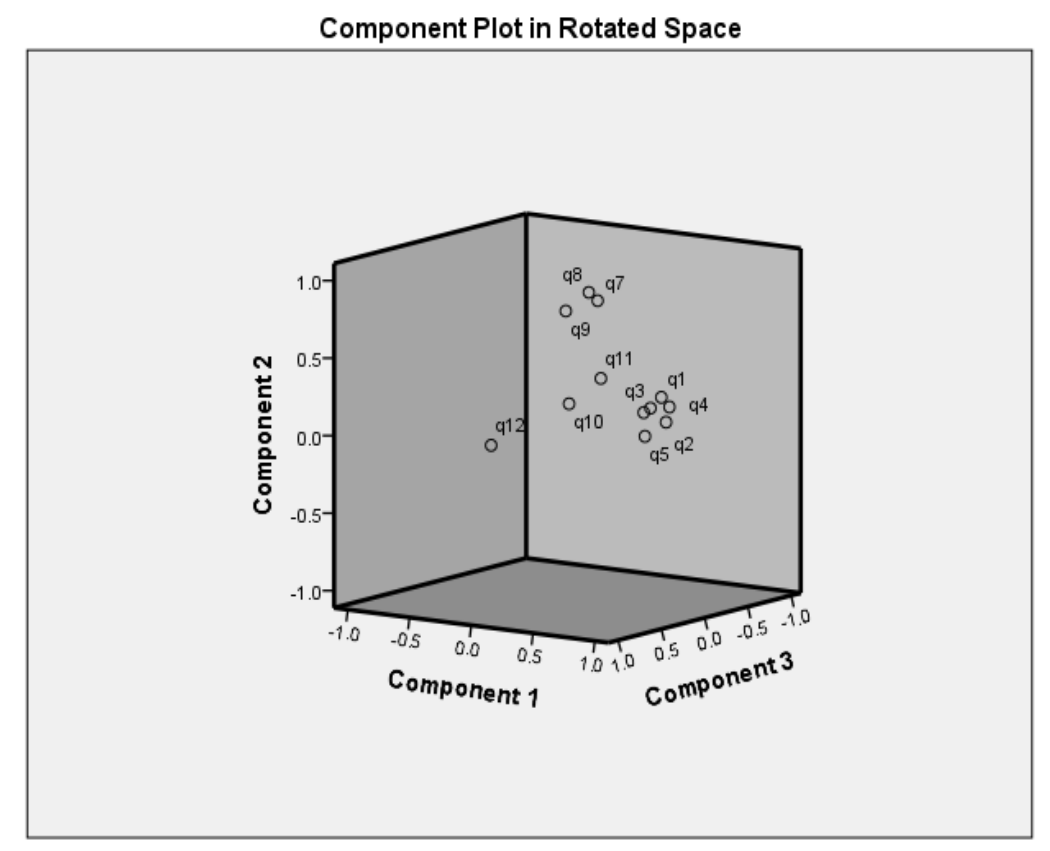

Figure 2. Rotated three-dimensional graph

The effect of factors on transfer of training:

In this section, the one sample t-test was used for analyzing the data. It should be noted that in examining research questions using one sample $t$ test, the higher level of experimental mean compared with population mean and significant level of calculated t-value are components' desirability criteria. Considering questionnaire scale (1-5 for very low to very high), the theoretical mean was determined to be $60 \%$ of highest score for each item. Given that the maximum score for each item is assumed to be 5 , therefore the $60 \%$ of $5(=3)$ is considered to be theoretical mean of each item. So, if the obtained mean is greater than 3 and the t-value is at a significant level, the item will be regarded as one of studied components; otherwise, the item or component will be assessed at low level.

Table 6. Descriptive statistics of factors affecting the transfer of training

\begin{tabular}{|c|c|c|c|c|c|}
\hline$\underbrace{\text { Index descriptive }}_{\text {Varia }}$ & & Number & Mean & Standard deviation & Standard error \\
\hline Management support & & 193 & 3.39 & 1.04 & 0.075 \\
\hline Peer support & & 193 & 3.46 & 0.89 & 0.064 \\
\hline Technological support & & 193 & 3.16 & 0.96 & 0.069 \\
\hline $\begin{array}{l}\text { Opportunity } \\
\text { capabilities }\end{array}$ & use & 193 & 3.53 & 0.69 & 0.050 \\
\hline
\end{tabular}


1. What is the role of management support on transfer of training to workplace from the perspective of Tehran Municipality employees?

Table 7. Management support from the perspective of Tehran Municipality employees

\begin{tabular}{|c|c|c|c|c|c|c|c|}
\hline & \multicolumn{7}{|c|}{ 3Test Value $=$} \\
\hline & \multirow{2}{*}{$\mathrm{T}$} & \multirow{2}{*}{$\begin{array}{l}\text { Degree } \\
\text { freedom }\end{array}$} & \multirow{2}{*}{ of } & \multirow{2}{*}{$\begin{array}{l}\text { Sig. level (two } \\
\text { range) }\end{array}$} & \multirow{2}{*}{$\begin{array}{l}\text { Mean } \\
\text { difference }\end{array}$} & \multicolumn{2}{|c|}{$\begin{array}{l}\% 95 \text { Confidence interval of } \\
\text { mean }\end{array}$} \\
\hline & & & & & & Minimum & Maximum \\
\hline First item & 7.84 & 192 & & 0.000 & 0.632 & 0.47 & 0.79 \\
\hline Second item & 5.09 & 192 & & 0.000 & 0.415 & 0.25 & 0.57 \\
\hline Third item & 1.58 & 192 & & 0.115 & 0.140 & -0.03 & 0.31 \\
\hline Management support & 5.24 & 192 & & 0.000 & 0.395 & 0.24 & 0.54 \\
\hline
\end{tabular}

Since the t-value of management support (5.24) (degrees of freedom=192) is greater than the critical t-value (1.96) at level 0.05 , it can be said with $95 \%$ confidence level that since the experimental mean of management support is higher, the management support impacts significantly on transfer of training.

2. What is the role of peer support on transfer of training to workplace from the perspective of Tehran Municipality employees?

Table 8. Peer support from the perspective of Tehran Municipality employees

\begin{tabular}{|c|c|c|c|c|c|c|c|}
\hline & \multicolumn{7}{|c|}{ 3Test Value $=$} \\
\hline & \multirow[t]{2}{*}{$\mathrm{T}$} & \multirow{2}{*}{$\begin{array}{l}\text { Degree } \\
\text { freedom }\end{array}$} & \multirow[t]{2}{*}{ of } & \multirow{2}{*}{$\begin{array}{l}\text { Sig. level (two } \\
\text { range) }\end{array}$} & \multirow{2}{*}{$\begin{array}{l}\text { Mean } \\
\text { difference }\end{array}$} & \multicolumn{2}{|c|}{$\begin{array}{l}\% 95 \text { Confidence interval of } \\
\text { mean }\end{array}$} \\
\hline & & & & & & Minimum & Maximum \\
\hline Fourth item & 8.62 & 192 & & 0.000 & 0.620 & 0.48 & 0.76 \\
\hline Fifth items & 7.05 & 192 & & 0.000 & 0.526 & 0.38 & 0.67 \\
\hline Sixth items & 3.09 & 192 & & 0.002 & 0.245 & 0.09 & 0.40 \\
\hline Peer support & 7.15 & 192 & & 0.000 & 0.463 & 0.33 & 0.59 \\
\hline
\end{tabular}

Since the t-value of peer support (7.15) (degrees of freedom=192) is greater than the critical t-value (1.96) at level 0.05 , it can be said with $95 \%$ confidence level that since the experimental mean of peer support is higher, the peer support impacts significantly on transfer of training. 
3. What is the role of technological support on transfer of training to workplace from the perspective of Tehran Municipality employees?

Table 9. Technological support from the perspective of Tehran Municipality employees

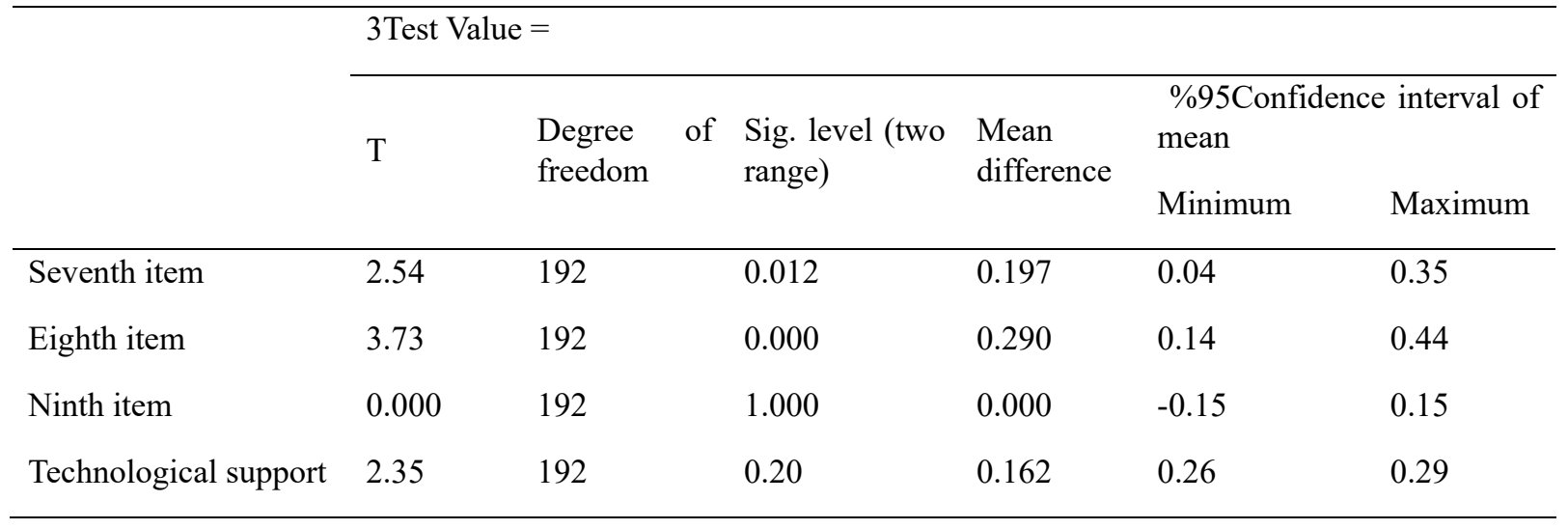

Since the t-value of technological support (2.35) is not greater than the critical t-value (1.96), the technological support has a moderate impact on transfer of training.

4. What is the role of opportunity to use capabilities on transfer of training to workplace from the perspective of Tehran Municipality employees?

Table 10. Opportunity to use capabilities from the perspective of Tehran Municipality employees

\begin{tabular}{|c|c|c|c|c|c|c|c|c|c|}
\hline & & & \multicolumn{7}{|c|}{3 Test Value $=$} \\
\hline & & & \multirow[t]{2}{*}{$\mathrm{T}$} & \multirow{2}{*}{$\begin{array}{l}\text { Degree } \\
\text { freedom }\end{array}$} & \multirow[t]{2}{*}{ of } & \multirow{2}{*}{$\begin{array}{l}\text { Sig. level (two } \\
\text { range) }\end{array}$} & \multirow{2}{*}{$\begin{array}{l}\text { Mean } \\
\text { difference }\end{array}$} & \multicolumn{2}{|c|}{$\begin{array}{l}\% 95 \text { Confidence interval of } \\
\text { mean }\end{array}$} \\
\hline & & & & & & & & Minimum & Maximum \\
\hline Tenth item & & & 14.27 & 192 & & 0.000 & 0.948 & 0.82 & 1.08 \\
\hline Eleventh item & & & 7.29 & 192 & & 0.000 & 0.477 & 0.35 & 0.61 \\
\hline Twelfth item & & & 2.30 & 192 & & 0.22 & 0.176 & 0.03 & 0.33 \\
\hline $\begin{array}{l}\text { Opportunity } \\
\text { capabilities }\end{array}$ & to & use & 10.68 & 192 & & 0.000 & 0.533 & 0.43 & 0.63 \\
\hline
\end{tabular}

Since the t-value of opportunity to use capabilities (10.68) (degrees of freedom=192) is greater than the critical t-value (1.96) at level 0.05 , it can be said with $95 \%$ confidence level that since the experimental mean of opportunity to use capabilities is higher, the opportunity to use capabilities impacts significantly on transfer of training. 
Table 11. Ranking of factors affecting transfer of training

\begin{tabular}{llllll}
\hline Components & $\begin{array}{l}\text { Ranking } \\
\text { mean }\end{array}$ & Priority & df & Chi- square & Sig. level \\
\hline Opportunity to use capabilities & $\mathbf{2 . 7 8}$ & First & & & \\
Peer support & $\mathbf{2 . 5 9}$ & Second & $\mathbf{3}$ & $\mathbf{2 3 . 3 7}$ & $\mathbf{0 . 0 0 0}$ \\
Management support & $\mathbf{2 . 4 1}$ & Third & & & \\
Technological support & $\mathbf{2 . 2 2}$ & Third & & & \\
\hline
\end{tabular}

According to above table, the Friedman non-parametric test was used to prioritize the training transfer components as: opportunity to use capabilities, peer support, management support, and technological support.

\section{Discussion and Conclusion}

This study aimed to investigate the role of environment factors affecting the transfer of Employees's training in Tehran Municipality. The data were collected using Shams Moorkani and Daneshmandi's Standardized Questionnaire (12 items) (2014) which is based on important environment factors (management support, peer support, technological support, and opportunity to use capabilities).

According to results of factor analysis and indices, three extracted items explained $67.49 \%$ of total variance. The first (eigenvalue $=5.45$ ), second (eigenvalue $=1.58$ ), and third (eigenvalue $=1.06$ ) items explained $45.42,13.19$, and 8.86 percent of total variance, respectively.

The least common thing (0.464) was for item 10 (motivation to use learned capabilities in work place) and the most common thing $(=0.810)$ was for item 12 (daily work tasks do not let to use learned capabilities in job).

The Friedman non-parametric test was used to prioritize the training transfer components as: opportunity to use capabilities, peer support, management support, and technological support. Also, the one-sample t-test was used to measure the effect of each factor. Accordingly, the test results are as follows:

Investigating the impact of management support on Employee's training transfer, it was shown that according to Tehran Municipality Employees, the management support impacts significantly $(=5.24)$ on transfer of training. The research suggested that when employees find their managers support from using new knowledge and skills in workplace, they will be more willing to transfer the competencies to workplace (Velada \& Caetano, 2007). This finding is consistent with findings of Baldwin and Ford (1988), Halton (2000), gil, Molina \& Ortega (2016), Landsman (2007), Brooke \& Hotchinz (2008), Murbarak (2009), Aurbakhu, McGowan \& LaPorte (2008), and Shams Moorkani and Daneshmandi (2014). 


\section{Macrothink}

Also, the results showed that peer support $(=7.15)$ has been effective in transferring training to workplace. This suggests that after returning from a training course, if the individuals are requested to share contents, and to be encouraged to use learned skills, they definitely will try to transfer their training to workplace. This is consistent with finding of Fastener and Grouber (2008); they showed that the peers support types include: 1: Accepting the change in behavior of colleagues, and 2: Asking them to share experiences and learned content. Several studies have shown that the peers support plays an important role in transfer of training to workplace (Brook \& Hotchinz (2008), Kulkuit (2000), Derji (2005), and Shams Moorkani and Daneshmandi (2014)).

Investigating the impact of technological support on employee's training transfer, it was shown that according to Tehran Municipality Employees, the management support has a moderate impact $(=2.35)$ on transfer of training. This is consistent with finding of Shams Moorkani and Daneshmandi (2014).

Also, investigating the impact of opportunity to use capabilities on employee's training transfer, it was shown that according to Tehran Municipality Employees, the opportunity to use capabilities has a high impact $(=10.68)$ on transfer of training. This is consistent with finding of Lim and Johnson (2002) and Merriam and Leahy (2005).

\section{References}

Abozed .M, Melanie, Y., \& Saci, K. (2008). Motivation to Transfer Training In the Libyan Oil Industry: Role of Work Environmental Factors and Organizational Culture.

Auerbach, C., McGowan, B., \& LaPorte, H.H. (2008). How does professional education impact the job outlook of public child welfare workers? Journal of Public Child Welfare, 1(3), 55-76. https://doi.org/10.1300/J479v01n03_04

Baldwin, T. T. \& Ford, J. K. (1988). Transfer of training: A review and directions for future research. Personnel Pychology, 61, 63-105. https://doi.org/10.1111/j.1744-6570.1988.tb00632.x

Brinkerhoff, R. O., \& Montesino, M. U. (1995). Partnerships for training transfer: Lessons from a corporate Study. Human Resource Development Quarterly, 6(3), 263-274. https://doi.org/10.1002/hrdq.3920060305

-Bouzguenda, K. (2014). Enablers and Inhibitors of Learning Transfer from Theory to Practice. In Transfer of Learning in Organizations. Springer International Publishing. https://doi.org/10.1007/978-3-319-02093-8_3

Burke, L. A., \& Hutchins, H. M. (2008). A study of best practices in training transfer and proposed model of training. Human resource development quarterly, 19(2), 107-128. https://doi.org/10.1002/hrdq.1230

Colquitt, Le Pine, \& Noe. (2000). Toward an integrative theory of training motivation: A meta-analytic path analysis of 20 years of research. Journal of Applied Psychology, 85(5), 678-707. https://doi.org/10.1037/0021-9010.85.5.678 
Cromwell, S. E., \& Kolb, J. A. (2004). An examination of work-environment support factors affecting Transfer of supervisory skills training to the workplace. Human Resource Development Quarterly, 15(4), 449-471. https://doi.org/10.1002/hrdq.1115

Doyle, S. (2002). Putting Learning to Work: the Distance Learning and Transfer of Learning. New Zealand Council for Educational Research, New Zealand. Retrieved from http://www.nzcer.org.nz/pdfs/10355.pdf.

Dorji, R. (2005). Transfer of learning from the out-country training programs (Ministry of Education, Bhutan) Royal Government of Bhutan (M.A. Thesis, School of Education \& Community Studies, University of Canberra).

Elangovan, A. R., \& Karakowsky, L. (1999). The role of trainee and environmental factors in transfer of Training: an exploratory framework. Leadership \& Organization Development Journal, 20(5), 268-276. https://doi.org/10.1108/01437739910287180

Fridman, S. H., \& Ronen, S. (2015). The Effects of Implementation Intentions on Transfer of Training. Department of Organizational Behavior, Tel Aviv University. https://doi.org/10.1002/ejsp.2114

Gil, A., Molina, J., \& Ortega, R. (2016). Determinants of training transfer in the wine industry: conceptual hypotheses and results for Rioja (Spain). Journal of Wine Research, 1-18. https://doi.org/10.1080/09571264.2015.1116440

Holton, E. F. III., Bates, R., \& Ruona, W. E. A. (2000). Development of a Generalized Learning Transfer System Inventory. Human Resources Development Quarterly, 11(4), 333-360. https://doi.org/10.1002/1532-1096 (200024)11:4<333: AID-HRDQ2>3.0.CO;2-P

Landsman, M. J. (2007). Supporting child welfare supervisors to improve worker retention. Child welfare, 86(2), 105-124.

Leberman, S., McDonald, L., \& Doyle, S. (2006). The transfer of learning: Participants' perspectives of adult education and training. Gower Publishing, USA.

Lim, D. H., \& Johnson, S. D. (2002). Trainee perceptions of factors that influence learning transfer. International Journal of Training and Development, 6, 36-48. https://doi.org/10.1111/1468-2419.00148

Merriam, L. (2005). Learning transfer. PAACE Journal of Lifelong Learning, 14.

Mohammed Turab, G., \& Casimir, G. (2015). A model of the antecedents of training transfer. International Journal of Training Research, 13(1), 82-95. https://doi.org/10.1080/14480220.2015.1051352

MorBarak, M. E. (2009). The impact of supervision on worker outcomes: a meta - analysis. Social service review, 83(1), 3-32. https://doi.org/10.1086/599028

Noe, R. A. (2010). Employee training and development. New York: McGraw-Hill.

Schmitz, M. (2009). Report on transfer of training. D5.4.1 
Schneider, K., Pältz, M., \& Stauche, H. (2014). Transfer of Learning in organizations. In K. Schneider (Ed.), Transfer of Learning in Organizations. Cham: Springer International Publishing. https://doi.org/10.1007/978-3-319-02093-8

Shams Mourakani, Gh \& Daneshmandi, S. (2014). The important role of environmental factors on transfer of training: case stud. Managing Education in Organizations, 3(1), 9-44

Sookhai, F., \& Budworth, M. H. (2010). The trainee in context: Examining the relationship between self-efficacy and transfer climate for transfer of training. Human Resource Development Quarterly, 21(3), 257-272. https://doi.org/10.1002/hrdq.20044

Taghavi Fard, M., Rahimian, H., \& Najafi, A. (2015). The Study of the Status of Training Transfer and Prioritizing its Influencing Factors in the National Petrochemical Industry with Group Hierarchy Process Technique. Journal of Training and Development of Human Resources, 2(6), 75-101.

Velada, R., \& Caetano, A. (2007). Training transfer: the mediating role of perception of learning. Journal of European Industrial Training, 31, 283-96. https://doi.org/10.1108/03090590710746441

Yamnill, S., \& McLean, G. N. (2001). Theories supporting transfer of training. Human Resource Development Quarterly, 12(2), 195-208. https://doi.org/10.1002/hrdq.7

\section{Copyright Disclaimer}

Copyright for this article is retained by the author(s), with first publication rights granted to the journal.

This is an open-access article distributed under the terms and conditions of the Creative Commons Attribution license (http://creativecommons.org/licenses/by/4.0/). 